\title{
Influence of sediment on pelagic carbon and nitrogen turnover in a shallow Danish estuary
}

\author{
Mathias Middelboe ${ }^{1, *}$, Niels Kroer ${ }^{2}$, Niels O. G. Jørgensen ${ }^{1}$, Dean Pakulski ${ }^{3}$ \\ 'Section for Microbiology \& Genetics, Department of Ecology and Molecular Biology, The Royal Veterinary and Agricultural \\ University, Thorvaldsensvej 40, DK-1871 Frederiksberg C, Denmark \\ ${ }^{2}$ Department of Marine Ecology and Microbiology, National Environmental Research Institute, DK-4000 Roskilde, Denmark \\ ${ }^{3}$ US EPA Environmental Research Laboratory, Gulf Breeze, Florida 32561, USA
}

\begin{abstract}
The impact of sediment on pelagic microbial processes was examined for 3 different sediment types (a bare sandy sediment, an eelgrass sediment and a diatom sediment) in a shallow Danish estuary. Diel and seasonal variations in the in situ fluxes and pelagic turnover of various $\mathrm{C}$ and $\mathrm{N}$ compounds were measured in plexiglas chambers incubated on top of the sediment and related to parallel control incubations without sediment contact. In April, the microbial activity was low, and the sediment had relatively little influence on the pelagic $C$ and $N$ turnover. In August, however, the eelgrass and diatom sediments had a significant stimulatory effect on the bacterial production, which was 2 to 4 times higher than at the bare sediment station. The measured effects of the sediment on pelagic $\mathrm{C}$ and $\mathrm{N}$ turnover, thus, appeared to be related to the presence and activity of benthic microalgae and macrophytes. Stimulation of bacterial production by the sediment was in all experiments associated with a net flux of dissolved organic carbon (DOC) from the sediment. We suggest that the release of biodegradable DOC from benthic microalgae and macrophytes caused a stimulation of the bacterioplankton production. Since 2 to 4 times more nitrogen was retained in the pelagic bacterial biomass at the eelgrass and diatom sediment than at the bare sediment location, we suggest that the presence of benthic microalgae and macrophytes may cause a temporary immobilization of $\mathrm{N}$ in bacterioplankton biomass.
\end{abstract}

KEY WORDS: Sediment effect $\cdot$ Bacterioplankton $\cdot \mathrm{C}$ and $\mathrm{N}$ turnover $\cdot$ DOC release

\section{INTRODUCTION}

In oceanic environments, phytoplankton primary production is the dominant source of organic matter for bacterioplankton (e.g. Ducklow et al. 1993). In coastal waters, sediment and benthic macrophytes may also affect the pelagic nutrient cycling (Pakulski 1986, Turner 1993). Sedimentation of organic matter often leads to a rapid mineralization that causes a flux of inorganic nutrients back into the water column (Sloth et al. 1995). Despite a rapid turnover of dissolved organic nitrogen and carbon (DON and DOC) in

\footnotetext{
- Present address: Marine Biological Laboratory, University of Copenhagen, Strandpromenaden 5, DK-3000 Helsingør, Denmark. E-mail:middelboe@inet.zitech.dk
}

sediment, the pore water often contains residual pools of labile organic compounds, such as dissolved free amino acids, in concentrations that are 5 to 100 times higher than in the water column above the sediment (Boon 1986, Lomstein et al. 1995). Considering the concentration gradients in the sediment-water interface, a transport of organic nutrients from the sediment to the overlying water would be expected. Efflux of DON has been found to be equal to or higher than the amount of dissolved inorganic $N$ (DIN) released from the sediment (Christensen et al. 1983, Lomstein \& Blackburn 1992, Sloth et al. 1995).

The efflux of organic compounds from sediments may be influenced by factors other than diffusion. The composition of the sediment and the temperature have also been found to influence the efflux (Holmer 1996). Bacteria, benthic microalgae and macrophytes 
may retain $\mathrm{C}$ and $\mathrm{N}$ in the sediment by incorporating nutrients into their biomass and, hence, reduce the efflux of nutrients (Pedersen \& Borum 1992, Kairesalo et al. 1996). On the other hand, benthic micro- and macrophytes may contribute to the DON and DOC pools in the water column by releasing dissolved organic compounds (Hough \& Wetzel 1975, Jørgensen et al. 1981, Pakulski 1986, Turner 1993, Mann \& Wetzel 1996).

The quantitative importance for pelagic processes of nutrient fluxes across the sediment-water interface is poorly studied. It has previously been hypothesized that leachates from benthic macrophytes may influence the pelagic microbial processes and community respiration (Pakulski 1986, Turner 1993). The actual effects of the release of DOM and inorganic nutrients from the sediment on the pelagic bacterial $\mathrm{C}$ and $\mathrm{N}$ turnover will depend on the amount and composition of the released material, and on the growth limiting factors for the bacterioplankton.

The purpose of this study was to measure fluxes of dissolved organic and inorganic material from 3 different sediments (a bare sediment, an eelgrass-covered sediment and a diatom-covered sediment), and to examine the effects of these fluxes on the bacterioplankton nutrient turnover. This is, to our knowledge, the first attempt to directly measure effects of different sediment types on pelagic processes on a diel and seasonal time scale.

\section{MATERIALS AND METHODS}

Study area and experimental design. The studies were carried out in the Limfjord, Denmark, south of the Aggersund Bridge in April and August 1995. In situ fluxes and pelagic turnover of various $C$ and $N$ compounds were measured in triplicate $29 \mathrm{l}$ transparent plexiglas chambers $(29 \times 29 \times 34.5 \mathrm{~cm})$ placed on the sediment at 1 to $1.5 \mathrm{~m}$ depth. Chambers were incubated for 2 to $8 \mathrm{~h}$ on a bare sandy sediment ('bare sediment'), on eelgrass-covered sediment ('eelgrass sediment'), and on sediment covered with a diatom biofilm ('diatom sediment'; only August). In situ water circulation was simulated by an electric stirring rod fitted on the lid of the chamber. Duplicate or triplicate 21 polycarbonate bags or 11 glass bottles without sediment contact were used as controls. The controls were suspended in the water column ca $10 \mathrm{~cm}$ above the sediment surface. Incubations were performed both day and night.

Subsamples for chemical analyses and microbial activity (see below) were taken from the chambers at time zero and by the end of the incubation. In the diatom sediment experiment, additional samples for chemical analyses were taken every half hour during the incubation.

Dilution cultures. To estimate the bacterial content of $\mathrm{C}$ per unit of biovolume, batch cultures were set up in April. In these cultures, growth medium was prepared by filtering water from the field location through $142 \mathrm{~mm}$ Millipore GV filters (0.22 $\mu \mathrm{m}$ pore size) (Millipore, Bedford, USA), using a Millipore stainless steel filter holder and a Millipore peristaltic pump. Water used for bacterial inoculum was filtered through $47 \mathrm{~mm}$ Nuclepore polycarbonate membranes $(0.8 \mu \mathrm{m}$ pore size) (Nuclepore, Cambridge, USA) to remove bacterivores. Cultures were set up by inoculating the $0.22 \mu \mathrm{m}$ filtered water with $10 \%$ by volume of the $0.8 \mu \mathrm{m}$ filtered water. The dilution of the inocula ensured that the cultures were free of particulate detritus. Cultures were incubated in the dark at room temperature. Samples for particulate organic carbon (POC), bacterial counts and biovolumes were taken at $24 \mathrm{~h}$ intervals (see below)

Chemical analyses. Samples for dissolved free amino acids (DFAA), dissolved combined amino acids (DCAA), urea and inorganic nitrogen $\left(\mathrm{NH}_{4}{ }^{+}\right.$and $\left.\mathrm{NO}_{3}{ }^{-}\right)$ were filtered through $0.2 \mu \mathrm{m}$ sterile filters (Minitan, Sartorius, Göttingen, Germany) and stored frozen. Concentrations of DFAA were measured by high performance liquid chromatography (HPLC) after precolumn derivatization with o-phthaldialdehyde (Lindroth \& Mopper 1979, Jørgensen et al, 1993). For measurements of DCAA, $1 \mathrm{ml}$ subsamples were freezedried and hydrolyzed in vapor phase under nitrogen atmosphere for $20 \mathrm{~min}$ at $150^{\circ} \mathrm{C}$ by a microwave technique (Jørgensen \& Jensen 1997). The hydrolyzed material was redissolved in borate buffer at $\mathrm{pH}>10$ after which the amino acid content was quantified as individual free amino acids by HPLC.

Samples for total organic carbon (TOC) were stored frozen in precombusted $\left(500^{\circ} \mathrm{C}\right.$ overnight) glass tubes and measured by high temperature catalytic oxidation (oxidation at $680^{\circ} \mathrm{C}$, Pt-covered alumina beads as catalyst) on a Shimadzu TOC-5000 Analyzer (Shimadzu Corp., Japan) after removal of inorganic carbon by acidification with conc. HCl (Suprapur ${ }^{B}$, Merck, Darmstadt, Germany) and purging with nitrogen gas for $10 \mathrm{~min}$ (Kroer 1993). Concentrations of DOC were calculated by subtraction of POC from TOC.

Total dissolved $N$ (TN) was measured by high temperature catalytic oxidation (oxidation at $800^{\circ} \mathrm{C}$, Pt-covered alumina beads as catalyst) and detection by chemiluminescence upon reaction with ozone on a Mitsubishi Total Nitrogen Analyzer TN-05 (Mitsubishi Kasei Corp., Japan). DON concentration was calculated by subtracting amounts of dissolved inorganic $\mathrm{N}$ (see below) 
Ammonium and nitrate were measured using standard procedures (Technicon, Tarrytown, USA). Concentrations of urea were determined by the diacetyl monoxime method according to Price \& Harrison (1987)

Chlorophyll a (chl a) of sediment cores $(27 \mathrm{~mm}$ diameter) was extracted in $6 \mathrm{ml}$ of $96 \%$ ethanol at $-18^{\circ} \mathrm{C}$ for 2 to $3 \mathrm{~d}$. Chl a in $100 \mathrm{ml}$ water samples, filtered onto $25 \mathrm{~mm}$ Whatman GF/F filters (Whatman, Maidstone, England), was extracted in $3 \mathrm{ml} 96 \%$ ethanol. Chl a concentrations were determined spectrophotometrically.

Biomass and biovolume determination. Bacterial samples were preserved with $0.2 \mu \mathrm{m}$ filtered formaldehyde ( $2 \%$ final concentration) and counted after staining with acridine orange (Hobbie et al. 1977). In the April experiment the sizes of the bacteria were determined. Acridine orange stained cells were photographed using a Zeiss Axiovert 100TV epifluorescence microscope fitted with a Photometrics AT200 CCD camera (Photometrics Ltd, Arizona, USA) and analyzed by the NIH Image 1.59 Software. The image analysis method was based on an edge detection algorithm described by Viles \& Sieracki (1992) and B. H. Hygum (unpubl.). Photographs were taken from randomly selected fields. The biovolume of the cells was calculated according to the formula:

$$
\text { Volume }=8.5 \times A^{2.5} \times P^{-2}
$$

where $A$ is the area and $P$ the perimeter of the cells. A total of 200 to 8000 cells were measured per sample.

The photomicrographs of bacteria were calibrated with photomicrographs of YG Fluoresbrite ${ }^{\mathrm{rm}}$ microspheres (Polysciences, Inc., Warrington, USA) of 0.21 , 0.51 and $1.07 \mu \mathrm{m}$ diameter. The bacterial size did not change systematically during the experiments, and the mean bacterial cell volume was $0.048 \pm 0.011 \mu^{3}$.

For bacterial POC analysis in the dilution culture experiment in April, 200 to $400 \mathrm{ml}$ of water was filtered though precombusted $\left(450^{\circ} \mathrm{C}, 4 \mathrm{~h}\right) 25 \mathrm{~mm}$ Whatman $\mathrm{GF} / \mathrm{F}$ filters. After filtration, filters were dried and stored in a heated vacuum desiccator at $45^{\circ} \mathrm{C}$ until assayed on a Perkin Elmer 240C CHN Analyzer (Perkin Elmer, Norwalk, USA). To correct for carboncontaining particles in the culture medium and for adsorption of dissolved organics to the filters, 350 to $400 \mathrm{ml}$ of culture medium was filtered onto Whatman $G F / F$ filters and the carbon content subtracted from the bacterial POC values. Based on the POC measurements and the measured bacterial biovolumes an average carbon conversion factor of $0.412 \pm 0.310 \mathrm{pg} \mathrm{C}$ $\mu \mathrm{m}^{-3}$ was calculated.

Total POC was determined in triplicate on precombusted $13 \mathrm{~mm}$ Whatman GF/F filters by high temperature catalytic oxidation according to Søndergaard \& Middelboe (1993).
Correction for carbon on blank filters (no water filtered) was performed for all POC values

Measurements of bacterial activity. Bacterial uptake of DFAA was determined by incubating samples with an equimolar mixture of $4\left[{ }^{14} \mathrm{C}\right]$-labelled amino acids (glu, ser, gly, ala) with an individual specific activity between 58 and $282 \mathrm{mCi} \mathrm{mmol}^{-1}$ (Amersham, Buckinghamshire, England). Six nCi, corresponding to about $10 \mathrm{nM}$ amino acids, was added to $5 \mathrm{ml}$ duplicate subsamples and 1 killed control ( $2 \%$ formaldehyde, final concentration). Samples were incubated for 0.3 to $2 \mathrm{~h}$ to ensure a maximum uptake of $10 \%$ of the added tracer. The incubations were stopped with formaldehyde ( $2 \%$ final concentration). Samples were then filtered onto $0.2 \mu \mathrm{m}$ cellulose nitrate filters, rinsed 3 times with Milli- $Q$ water (Millipore) and radioassayed by liquid scintillation counting. Respiration of $\left[{ }^{14} \mathrm{C}\right]$ labelled amino acids during the incubations was assumed to be $50 \%$ of the uptake (Middelboe et al. 1995).

Turnover of DCAA was estimated by use of the fluorogenic substrate analog L-leucine-4-methylcoumarinylamide hydrochloride (Leu-MCA) (Hoppe et al. 1988, Middelboe et al. 1995). Triplicate $3 \mathrm{ml}$ subsamples were incubated with $500 \mathrm{nM}$ Leu-MCA (final concentration) for 2 to $10 \mathrm{~h}$. The increase in fluorescence was linear with time for the incubation times used. Leu-MCA turnover rate was calculated from the increase in fluorescence as the non-fluorescent Leu-MCA was hydrolyzed to the highly fluorescent 7-amino-4-methyl-coumarin (AMC). Background fluorescence at time zero was measured for each triplicate sample. Total DCAA uptake was estimated from concurrent measurements of Leu-MCA turnover and DCAA concentrations assuming 50\% respiration of the uptake (Middelboe et al. 1995).

Uptake (hydrolysis) of urea by the bacteria was measured from production of ${ }^{14} \mathrm{CO}_{2}$ in triplicate $20 \mathrm{ml}$ water samples to which $60 \mathrm{nCi}$ of ${ }^{14}$ [C]urea $(56 \mathrm{mCi}$ $\mathrm{mmol}^{-1}$, DuPont NEN Products Research Products, Denmark) was added. Samples were incubated in $100 \mathrm{ml}$ serum bottles with rubber septa to which plastic cups with accordion-folded paper wicks were fitted. Uptake was stopped after incubation periods of 2 to $3 \mathrm{~h}$ by injection of formaldehyde ( $2 \%$ final concentration) through the membrane. Samples were then acidified with $10 \%$ phosphoric acid, to drive off ${ }^{14} \mathrm{CO}_{2}$, and the wicks soaked with $500 \mu \mathrm{l}$ of Carbosorb $\mathrm{CO}_{2}$ absorber (Packard Instruments, Groningen, The Netherlands). After $1 \mathrm{~h}$ on a shaking table, the $\mathrm{CO}_{2}$ traps were transferred to $20 \mathrm{ml}$ scintillation vials and radioassayed.

Bacterial cell production was measured as bacterial incorporation of $\left[{ }^{3} \mathrm{H}\right]$-thymidine (Fuhrman \& Azam 1980), using a conversion factor of $1.1 \times 10^{18} \mathrm{cells} \mathrm{mol}^{-1}$ ${ }^{3} \mathrm{H}$-thymidine incorporated (Riemann et al. 1987). 
Table 1. Basic chemical and physical data (measured concentration ranges are shown). nd: not determined

\begin{tabular}{|c|c|c|c|c|c|c|c|c|c|c|}
\hline & $\begin{array}{l}\mathrm{NH}_{4}{ }^{+} \\
(\mu \mathrm{M})\end{array}$ & $\begin{array}{l}\mathrm{NO}_{3}^{-} \\
(\mu \mathrm{M})\end{array}$ & $\begin{array}{l}\text { Urea } \\
(\mu \mathrm{M})\end{array}$ & $\begin{array}{c}\text { DFAA } \\
(\mu \mathrm{M})\end{array}$ & $\begin{array}{c}\text { DCAA } \\
(\mu \mathrm{M})\end{array}$ & $\begin{array}{l}\text { TOC } \\
(\mu M)\end{array}$ & $\begin{array}{l}\text { POC } \\
(\mu M)\end{array}$ & $\begin{array}{l}\text { DON } \\
(\mu M)\end{array}$ & $\begin{array}{c}\text { Pelagic } \\
\text { chlorophyll } \\
\left(\mu \mathrm{g} \text { chl } a \mathrm{l}^{-1}\right)\end{array}$ & $\begin{array}{c}\text { Sediment } \\
\text { chlorophyll } \\
\left(\mu \mathrm{g} \text { chl } a \mathrm{~cm}^{-2}\right)\end{array}$ \\
\hline April & $1.2-3.1$ & $25.6-33.3$ & $1.4-1.9$ & $0.30-0.81$ & $1.1-1.4$ & $235-335$ & $46-75$ & nd & $1.1-1.7$ & nd \\
\hline August & $0.2-4.2$ & $0.3-1.7$ & $1.2-1.5$ & $0.21-1.3$ & $2.7-7.3$ & $495-700$ & $57-109$ & $30-100$ & $4.2-6.5$ & $2.37 \pm 0.83$ \\
\hline
\end{tabular}

\section{RESULTS}

\section{Concentrations and turnover of $\mathrm{C}$ and $\mathrm{N}$}

Pelagic concentrations of ammonium, urea and DFAA were within the same range in April and August (Table 1). DCAA concentrations, however, were significantly higher $(\mathrm{p}<0.05)$ and nitrate concentrations significantly lower in August than in April $(p<0.01$; Table 1). The concentration of TOC increased by a factor of 2 to 6 from April to August, while POC concentrations only showed a slight increase (Table 1), suggesting that the DOC concentration had increased. DFAA and DCAA constituted less than $1 \%$ of DOC at both sampling periods. POC constituted from 10 to $20 \%$ of the total pool of organic carbon. Pelagic chlorophyll concentrations were 3 to 4 times higher in August than in April. The chlorophyll concentration in the diatom sediment was $2.4 \mu \mathrm{g} \mathrm{chl} \mathrm{a} \mathrm{cm}^{-2}$ (Table 1). Unfortunately, the chlorophyll concentration in the bare sandy sediment was not measured.

The bacterial $\mathrm{C}$ and $\mathrm{N}$ demand and the uptake of DFAA were 5 to 10 times higher in August than in April, while DCAA and urea utilization were more than 50-fold higher (Fig. 1, Tables 2 \& 3). Thus, compared to DFAA, the relative importance of the DCAA and urea as $C$ and $N$ sources for the bacteria increased from April to August.

\section{Effect of sediment type on $\mathrm{C}$ and $\mathrm{N}$ fluxes and bacterioplankton activity}

In $\wedge$ pril, the effect of sediment on the pelagic microbial activities was limited (Table 2). The bare sediment significantly $(\mathrm{p}<0.01)$ stimulated the pelagic DFAA uptake during the night (Table 2), while the bacterial production was positively affected by the eelgrass sediment at night ( $\mathrm{p}<0.05$; Table 2 ). Other parameters were not significantly affected (Table 2).

Bacterial uptake of C and N (DFAA + DCAA + urea) did not differ significantly $(p>0.05)$ between bare sediment and eelgrass sediment in April (Fig. 1A-D). Measured $C$ uptake rates varied between 160 and
240 nmol $\mathrm{C}^{-1} \mathrm{~h}^{-1}$. The bacterial $\mathrm{C}$ and $\mathrm{N}$ demand, however, was almost 3 times higher in the eelgrass sediment incubation than in the bare sediment incubation (Fig. 1A-D). A net flux of $2.7 \pm 0.1 \mu \mathrm{mol} \mathrm{DOC} \mathrm{l}^{-1}$ $\mathrm{h}^{-1}$ from the eelgrass sediment into the water column (Fig. 1B) may have supported the increase in $\mathrm{C}$ demand (34 nmol $\mathrm{l}^{-1} \mathrm{~h}^{-1}$; Table 2), which corresponded to $1,3 \%$ of the DOC input. The discrepancy between the $\mathrm{N}$ uptake and the $\mathrm{N}$ demand probably indicates a mineralization of DON, as discussed later.

In August, the eelgrass sediment significantly stimulated the DFAA $(p<0.05)$ and DCAA $(p<0.01)$ assimilation in addition to the bacterioplankton production ( $\mathrm{p}<0.05$; Table 3 ). The bare sediment significantly stimulated the DCAA uptake $(\mathrm{p}<0.05$; Table 3$)$. This stimulation, however, was approximately 4 times smaller than for the eelgrass sediment (Table 3).

Similar to in April, bacterial C and $\mathrm{N}$ demands in August were significantly higher $(p<0.05)$ in the eelgrass

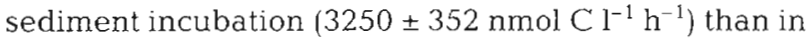
the bare sediment incubation $\left(1033 \pm 135 \mathrm{nmol} \mathrm{CI^{-1 }}\right.$ $\mathrm{h}^{-1}$ ) (Fig. 1). The bacterial $\mathrm{C}$ uptake in the eelgrass sediment incubation was not sufficient to sustain the $\mathrm{C}$ demand (Fig. 1F). However, similar to the experiment in April, a significant $(p<0.05)$ net DOC flux from the eelgrass sediment $\left(22 \pm 4 \mu \mathrm{mol} \mathrm{l}^{-1} \mathrm{~h}^{-1}\right)$ was observed (Fig. 1F). Despite this input of DOC, and a net efflux of DON from the eelgrass sediment (Fig. $1 \mathrm{H}$ ), the bacterial $\mathrm{C}$ and $\mathrm{N}$ uptake (DFAA + DCAA + urea) at this station was not significantly different from the bare sediment (Fig. 1E-H). As in the April experiments, a divergence between uptake and demand of $N$ was observed.

The effect of the diatom sediment was more complex than described above for the bare sediment and the eelgrass sediment (Table 3. Fig. 2). During the day, a significant $(p<0.05)$ positive effect on the DFAA and DCAA uptake rates and a stimulation of the bacterial production were found (Table 3 ). Urea turnover, on the other hand, was significantly reduced $(p<0.05)$. During the night, DCAA turnover was stimulated ( $p<0.05$ ) by the sediment, however, both DFAA uptake and bacterial production were reduced significantly $(p<$ $0.01)$ relative to the controls without sediment contact (Table 3). 

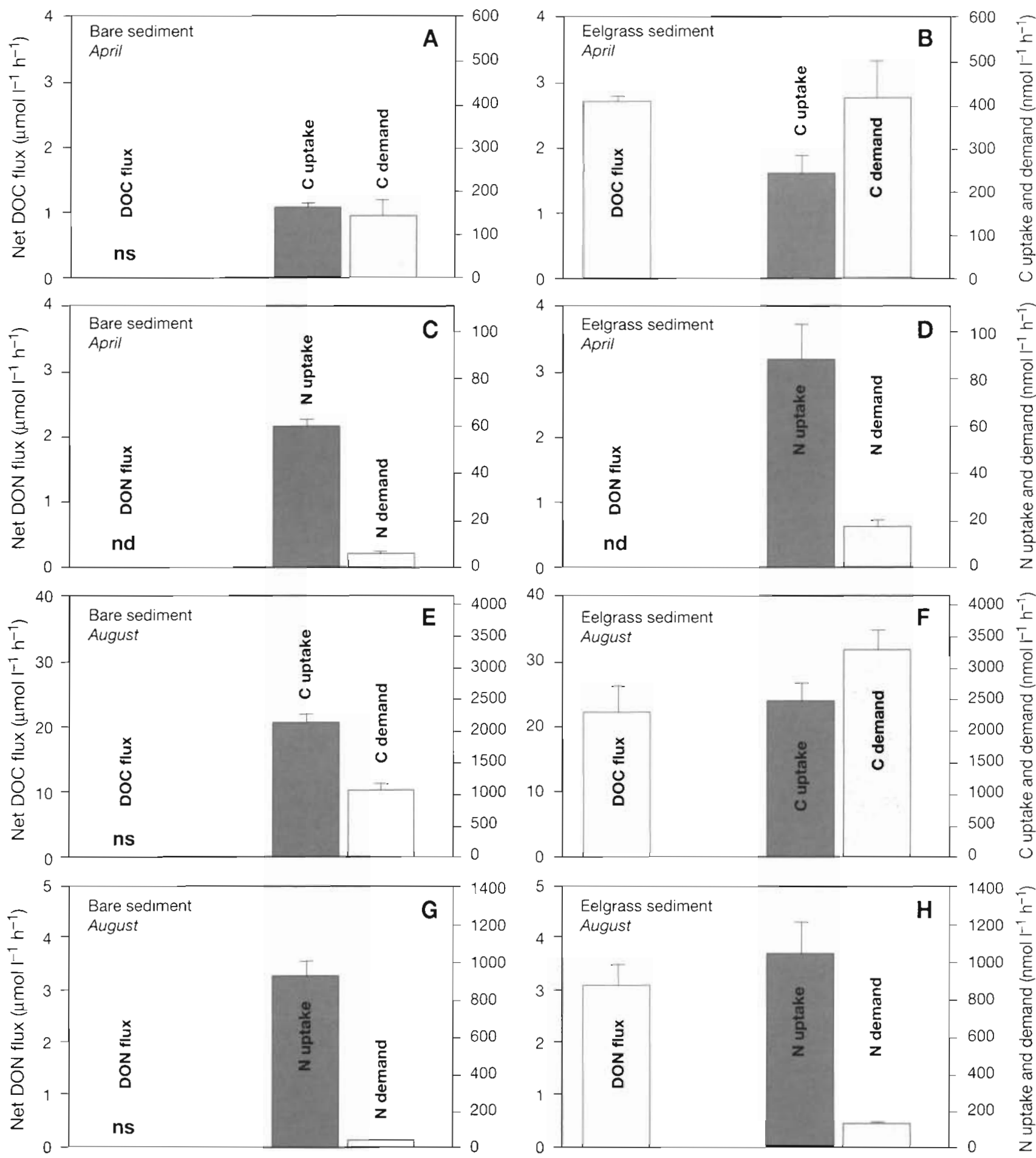

Fig. 1. Bacterial C and N uptake and demand and net fluxes of DOC and DON in the bare sediment and eelgrass sediment chambers from the April and August experiments. Rates are given as averages of the day and night values. Bacterial uptake of $C$ and $N$ was calculated as the sum of the uptake of DFAA, DCAA and urea, assuming an average $\mathrm{C}$ and $\mathrm{N}$ content of $3.1 \mathrm{C}$ atoms and 1.1 $\mathrm{N}$ atoms per amino acid. Bacterial $\mathrm{C}$ and $\mathrm{N}$ demand was calculated on the basis of cell production, using the measured cell biovolumes and the estimated carbon conversion factor. In addition, a growth efficiency of $20 \%$ (Middelboe et al. 1992) and a C:N ratio of 5 (Kroer 1994) were applied. Fluxes in DOC and DON between the sediment and water column were calculated by subtracting concentration changes in the controls from concentration changes in the water phase of the sediment chambers. (A-D) April experiments. ( $E-H)$ August experiments. Notice the different scales on the $y$-axes for flux rates and the rates of bacterial uptake and demand. Bars indicate + SD. ns: not significant; nd: not determined 
Table 2. Bacterioplankton production and turnover of DFAA, DCAA and urea, and the effect of sediment on the bacterial activities in the bare sediment and the eelgrass sediment in the April experiment $( \pm$ SD). The effect of sediment on the pelagic bacterial turnover of DFAA, DCAA and urea was assessed by subtracting the change in bacterial activity in the control bags from the change in activity in the sediment chambers during the incubation. Only significant effects are shown. Statistical significance (2 sample t-test): $p<0.05, \cdots p<0.01$; ns: not significant; nd: not determined

\begin{tabular}{|c|c|c|c|c|c|c|c|c|c|}
\hline & $\begin{array}{c}\text { DFAA } \\
\text { uptake } \\
\left.(\text { nmol }]^{-1} h^{-1}\right)\end{array}$ & $\begin{array}{c}\text { Effect of } \\
\text { sediment } \\
\left(n \text { mol } \mathrm{l}^{-1} \mathrm{~h}^{-1}\right)\end{array}$ & $\begin{array}{c}\text { DCAA } \\
\text { uptake } \\
\left(\text { nmol } \mathrm{l}^{-1} \mathrm{~h}^{-1}\right)\end{array}$ & $\begin{array}{c}\text { Effect of } \\
\text { sediment } \\
\text { (nmol } \mathrm{l}^{-1} \mathrm{~h}^{-1} \text { ) }\end{array}$ & $\begin{array}{c}\text { Urea } \\
\text { hydrolysis } \\
\left(\text { nmol }^{-1} \mathrm{~h}^{-1}\right)\end{array}$ & $\begin{array}{c}\text { Effect of } \\
\text { sediment } \\
\left.\text { (nmol } l^{-1} \mathrm{~h}^{-1}\right)\end{array}$ & $\begin{array}{c}\text { Bactenal } \\
\text { production } \\
\left(10^{6} \text { cells } \mathrm{l}^{-1} \mathrm{~h}^{-1}\right)\end{array}$ & $\begin{array}{r}\text { Effect } 0 \\
\left(10^{6} \text { cells } l^{-1} \mathrm{~h}\right.\end{array}$ & $\begin{array}{l}\text { diment } \\
\left.\text { Imol } \mathrm{Cl}^{-1} h^{-6}\right)^{e}\end{array}$ \\
\hline \multicolumn{10}{|c|}{ Bare sediment } \\
\hline Day & $25 \pm 2$ & ns & $4.7 \pm 1.3$ & ns & $0.21 \pm 0.05$ & $\mathrm{~ns}$ & $9.4 \pm 1.0$ & ns & ns \\
\hline Night & $73 \pm 1$ & $5.6 \pm 0.1 \cdots$ & $3.2 \pm 0.9$ & ns & $0.94 \pm 0.14$ & ns & $23 \pm 4$ & ns & ns \\
\hline \multicolumn{10}{|c|}{ Eelgrass sediment } \\
\hline Day & $93 \pm 4$ & ns & nd & nd & $1.32 \pm 0.16$ & ns & $42 \pm 2$ & ns & ns \\
\hline Night & $63 \pm 13$ & ns & nd & nd & $0.50 \pm 0.10$ & ns & $53 \pm 10$ & $3.8 \pm 1.4^{\circ}$ & $34 \pm 13^{\circ}$ \\
\hline
\end{tabular}

The bacterial $\mathrm{C}$ and $\mathrm{N}$ demand in the diatom sediment

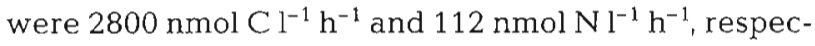
tively, during the day (Fig. 2A, C), i.e. significantly higher than for the bare sediment $(\mathrm{p}<0.05)$. Similar to the eelgrass sediment, the $C$ uptake could not support the $\mathrm{C}$ demand during the day, however, the high $\mathrm{C}$ demand coincided with the occurrence of a net flux of DOC from the sediment $\left(19 \mu \mathrm{mol} \mathrm{l}^{-1} \mathrm{~h}^{-1}\right)$ (Fig. 2A).

Although a turnover of DFAA and DCAA was demonstrated using radioisotopes and Leu-MCA, no significant net fluxes of DFAA or DCAA across the sediment were found at any of the sediment types (not shown). However, a significant efflux of ammonium was observed in the experiments with the diatom sediment (Fig. 3). During the day, concentrations increased by $2.3 \mu \mathrm{M}$ in the sediment chamber but decreased by $1.2 \mu \mathrm{M}$ in the control, resulting in a net flux of ammonium from the sediment of $0.89 \mu \mathrm{mol}$ $\mathrm{NH}_{4}^{+} \mathrm{l}^{-1} \mathrm{~h}^{-1}$ (Fig. 3A). During the night, the increase in ammonium concentration in the sediment chamber was $6.2 \mu \mathrm{M}$ and the decrease in the control $1.2 \mu \mathrm{M}$ (Fig. 3B), giving a net ammonium flux of $2.1 \mu \mathrm{mol}$ $\mathrm{NH}_{4}^{+} \mathrm{l}^{-1} \mathrm{~h}^{-1}$. There were no significant fluxes of nitrate or urea in these experiments (Fig. 3A, B). The net DON release in the diatom sediment incubation was 2.1 to 3.5 times higher than the net DIN release (Fig. 3).

\section{Diel differences in pelagic bacterial $\mathrm{C}$ and $\mathrm{N}$ turnover}

In the bare sediment experiments, the bacterial production was significantly higher $(\mathrm{p}<0.05)$ at night than

Table 3. Bacterioplankton production and turnover of DFAA, DCAA and urea, and the effect of sediment on the bacterial activities in the bare sediment, the eelgrass sediment, and the diatom sediment in the August experiment ( \pm SD). The effect of sediment on the pelagic bacterial turnover of DFAA, DCAA and urea was assessed by subtracting the change in bacterial activity in the control bags from the change in activity in the sediment chambers during the incubation. Only significant effects are shown. Statistical significance (2 sample $t$-test): $p<0.05, \cdots p<0.01$; ns: not significant

\begin{tabular}{|c|c|c|c|c|c|c|c|c|c|}
\hline & $\begin{array}{c}\text { DFAA } \\
\text { uptake } \\
\left(\text { nmol } h^{-1} h^{-1}\right)\end{array}$ & $\begin{array}{c}\text { Effect of } \\
\text { sediment } \\
\left(\text { nmol } l^{-1} h^{-1}\right)\end{array}$ & $\begin{array}{c}\text { DCAA } \\
\text { uptake } \\
\text { (nmol } \mathrm{l}^{-1} \mathrm{~h}^{-1} \text { ) }\end{array}$ & $\begin{array}{c}\text { Effect of } \\
\text { sediment } \\
\left(\text { nmol } l^{-1} h^{-1}\right)\end{array}$ & $\begin{array}{c}\text { Urea } \\
\text { hydrolysis } \\
\left(\text { nmol } \mathrm{l}^{-1} \mathrm{~h}^{-1}\right)\end{array}$ & $\begin{array}{c}\text { Effect of } \\
\text { sediment } \\
\left(\text { nmol } l^{-1} h^{-6}\right)\end{array}$ & $\begin{array}{c}\text { Bacterial } \\
\text { production } \\
\left(10^{6} \text { cells } \mathrm{l}^{-1} \mathrm{~h}^{-1}\right)\end{array}$ & $\begin{array}{r}\text { Effect of } \mathrm{s} \\
\left.\left(1,0^{6} \text { cells }\right)^{-1} \mathrm{~h}^{-1}\right)\end{array}$ & $\begin{array}{l}\text { sediment } \\
\left.\text { (nmol } \mathrm{Cl}^{-1} \mathrm{~h}^{-1}\right)^{a}\end{array}$ \\
\hline \multicolumn{10}{|c|}{ Bate sedinent } \\
\hline Day & $292 \pm 19$ & ns & $301 \pm 31$ & $22 \pm 12^{\circ}$ & $9.5 \pm 0.1$ & ns & $87 \pm 4$ & ns & ns \\
\hline Night & $438 \pm 29$ & ns & $330 \pm 11$ & ns & $166 \pm 350$ & ns & $150 \pm 15$ & ns & ns \\
\hline \multicolumn{10}{|c|}{ Eelgrass sediment } \\
\hline Day & $375 \pm 46$ & ns & $462 \pm 17$ & $84 \pm 12 \cdots$ & $141 \pm 59$ & ns & $339 \pm 16$ & $27 \pm 6^{\circ}$ & $240 \pm 53^{\circ}$ \\
\hline Night & $447 \pm 11$ & $58 \pm 7^{\cdot}$ & $297 \pm 79$ & ns & $36 \pm 22$ & ns & $404 \pm 37$ & $79 \pm 19^{\circ}$ & $688 \pm 166^{\circ}$ \\
\hline \multicolumn{10}{|c|}{ Dratom sediment } \\
\hline Day & $303 \pm 45$ & $58 \pm 12^{\circ}$ & $89 \pm 30$ & $16 \pm 8^{\circ}$ & $8.1 \pm 1.7$ & $-6.7 \pm 2.6$ & $319 \pm 37$ & $23 \pm 11^{\circ}$ & $197 \pm 94^{\circ}$ \\
\hline Night & $181 \pm 23$ & $-122 \pm 9^{\cdots}$ & $82 \pm 13$ & $12 \pm 5^{\circ}$ & $5.8 \pm 0.9$ & ns & $124 \pm 6$ & $-11 \pm 2^{\cdots}$ & $-95 \pm 17^{\prime \prime}$ \\
\hline
\end{tabular}



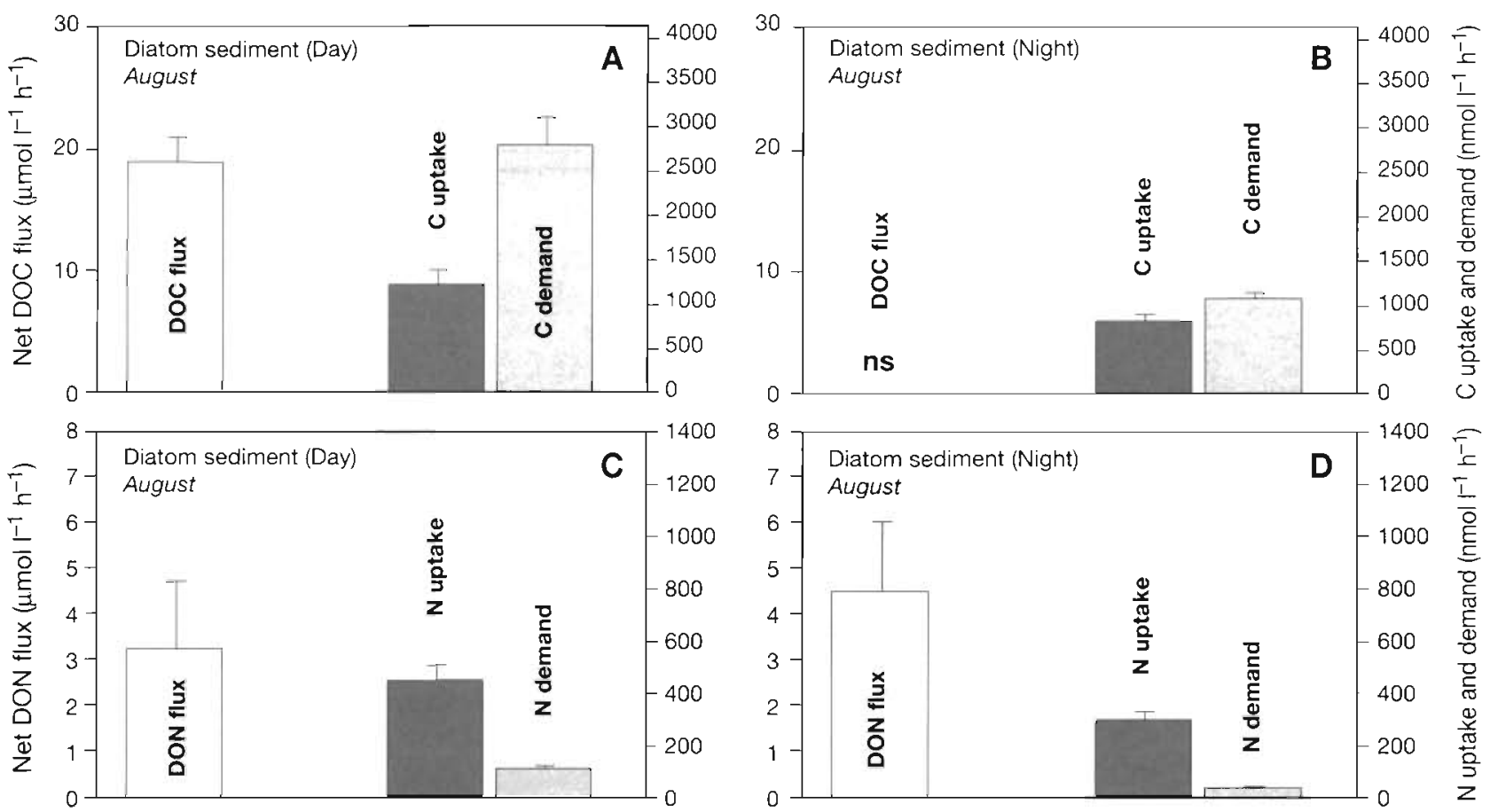

Fig. 2. Bacterial $\mathrm{C}$ and $\mathrm{N}$ uptake and demand and net fluxes of DOC and DON in the diatom sediment chambers in the August experiment. Values from both day and night experiments are presented. Uptake, demand and flux were calculated as described in the legend for Fig. 2. (A, C) Day experiment. (B, D) Night experiment. Notice the different scales on the $y$-axes for flux rates and the rates of baterial uptake and demand. Bars indicate $+\mathrm{SD}$. ns: not significant

during the day in both April and August (Tables $2 \& 3$ ). This enhanced production at night was in both seasons associated with significantly higher uptake of DFAA ( $p<0.05$; Tables $2 \& 3$ ). Also, urea turnover was higher at night on bare sediment ( $p<0.01$; Tables $2 \& 3$ ). The eelgrass sediment experiments, on the other hand, did not reveal significant diel variations in the measured microbial activities ( $p>0.05$; Tables $2 \& 3$ ).

In the diatom sediment experiment, diel variation in bacterial DFAA and DCAA uptake in the sediment chambers was significantly enhanced relative to the control in the day experiment $(p<0.05)$ (Table 3). Urea uptake, on the other hand, was significantly reduced $(\mathrm{p}<0.05)$. The bacterial $\mathrm{C}$ and $\mathrm{N}$ demand was about 3 times higher in the daytime than during the night ( $p<0.05 ;$ Fig. 2). Accordingly, DFAA uptake was lowest at night (Table 3 ).

\section{DISCUSSION}

\section{Effects of sediment on pelagic $\mathrm{C}$ and $\mathrm{N}$ concentrations and turnover}

This study shows that the sediments may have a significant impact on nutrient turnover in the overlying water. In the eelgrass and diatom sediment experi- ments (day expt), the bacterioplankton production was significantly affected by the sediment contact, and the production was significantly higher compared to the bare sediment (Tables $2 \& 3$ ).

The stimulation of bacterial production was, in all experiments, coupled with a net influx of DOC from the sediments. However, the increased production was not associated with an increased uptake of amino acids, nor was the sum of the uptake of $\mathrm{C}$ and $\mathrm{N}$ from DFAA, DCAA and urea significantly lower at the bare sediment than at the other sediments (Figs. $2 \& 3$ ). This suggested that the enhanced bacterial production was sustained by an input of labile DOM from the sediment and that this DOM had a low content of amino acids and urea.

The hypothesis that the bacterial production was sustained by an input of DOM other than amino acids and urea was supported by the relatively low contribution of DFAA and DCAA as C sources for the pelagic bacteria in the eelgrass and diatom sediment incubations compared to the bare sediment (Figs. $1 \& 2$ ). In the eelgrass and diatom sediments, DFAA and DCAA uptake could sustain $58 \%$ of the bacterial $C$ demand in April (eelgrass sediment only) and 43 to $75 \%$ of the demand in August (Figs. 1 \& 2). In the bare sediment, however, DFAA and DCAA contributed 114 and 204\% to pelagic bacterial $\mathrm{C}$ demand in April and August, 

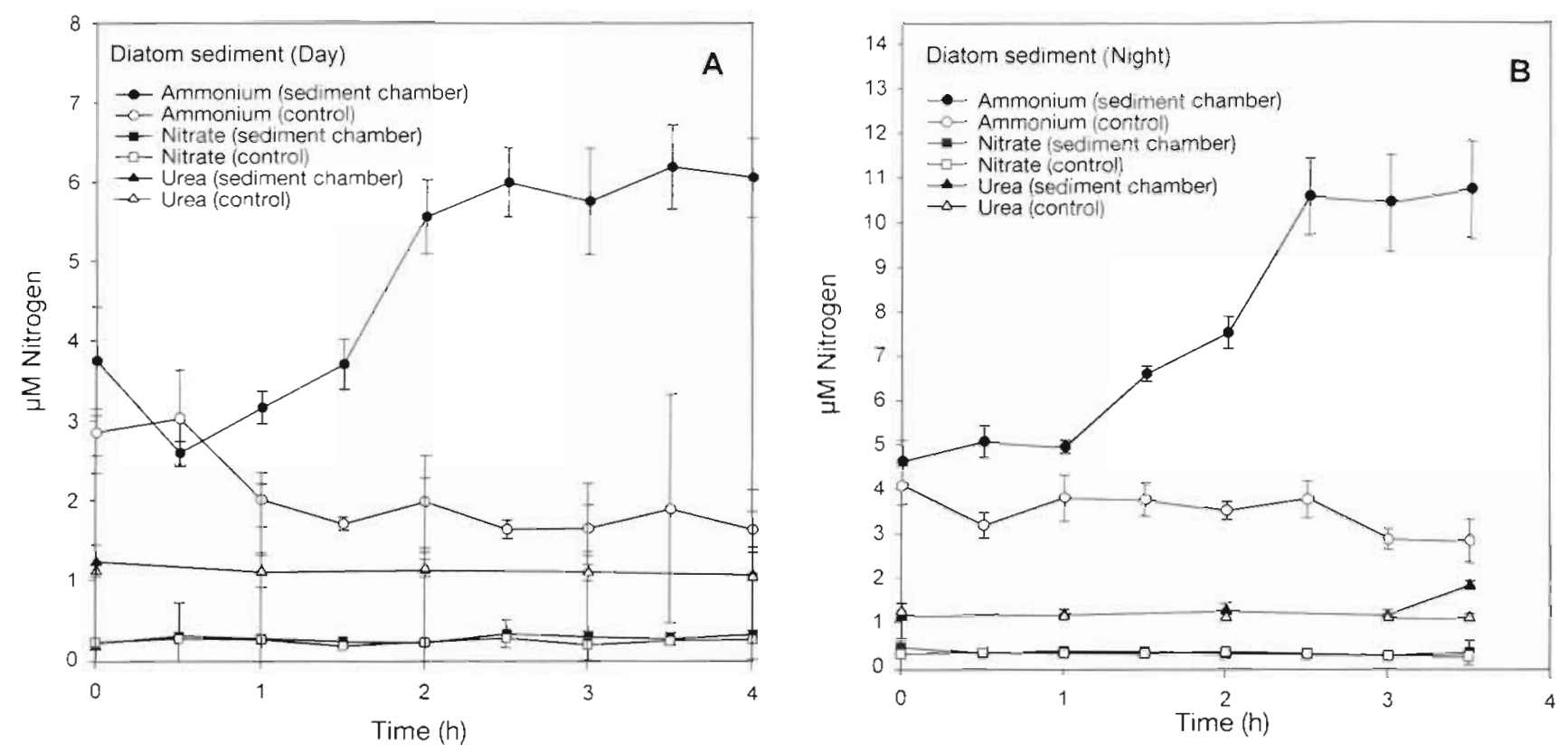

Fig. 3. Time course of the concentration of $\mathrm{NH}_{4}{ }^{+}, \mathrm{NO}_{3}^{-}$, and urea in the sediment chambers and the controls during the (A) day and $(B)$ night incubations at the diatom sediment station. Bars indicate \pm SD

respectively (Fig, 1). It should be noted that the contribution of DCAA to bacterial $\mathrm{C}$ and $\mathrm{N}$ demand was based on bacterial hydrolysis of a model peptide (Leu-MCA) and was not a direct measure of bacterial DCAA uptake. The method assumed all the measured DCAA to be potential substrates for the extracellular aminopeptidase. Since only a part of the measured DCAA may constitute a substrate for bacterial extracellular hydrolysis (Keil \& Kirchman 1993), rates of DCAA hydrolysis based on Leu-MCA are probably overestimated. On the other hand, the aminopeptidases as detected by Leu-MCA may not fully reflect total bacterial protease activity (Middelboe et al. 1995). Overall, Middelboe et al. (1995) suggested that the Leu-MCA hydrolysis approach may underestimate total DCAA hydrolysis.

The effect of the DOC release on the bacterial carbon demand (Tables 2 \& 3) indicated that only a few percent of the DOC was taken up within the incubation period ( 2 to $7 \mathrm{~h}$ ). Previous studies have demonstrated leaching of DOM from submerged macrophytes (Pakulski 1986, Turner 1993). Pakulski (1986) found that Spartina alterniflora in a salt marsh. released significant amounts of monosaccharides, corresponding to $1-2 \%$ of the total DOC release from the plants. Based on the composition of the DOM and the rate of its release, the authors suggested that the losses of labile DOM from the macrophytes constitute an important substrate source for the pelagic bacteria (Pakulski 1986, Turner 1993). Similarly, microalgae have been shown to release low molecular weight
DOC, which was readily taken up by bacteria (Jensen 1983). These studies, thus, support our hypothesis that DOC, possibly as carbohydrates, was released from the benthic flora and subsequently taken up by pelagic bacteria.

In both April and August, bacterial $N$ uptake (DFAA + DCAA + urea) exceeded their estimated $N$ demand (Figs. $1 \& 2$ ). If ammonium was also used by the bacteria in the experiments as an additional $\mathrm{N}$ source (Kirchman et al. 1989, Middelboe et al. 1995) the measured $\mathrm{N}$ uptake may underestimate the bacterial $\mathrm{N}$ uptake. Consequently, the excess uptake of $\mathrm{N}$ relative to the bacterial demand may be even larger than indicated in Figs. 1 \& 2. This apparent excess bacterial $N$ uptake may indicate that bacteria acted as net mineralizers of $\mathrm{N}$ in the incubations. However, the rather invariable concentrations of inorganic $\mathrm{N}$ found in the experiments imply that, if the bacterioplankton mineralized the excess uptake of DON, the produced inorganic $\mathrm{N}$ must have been taken up immediately by the phytoplankton. The low pools of ammonium (April and August) and nitrate (August) may support a high demand for DIN by photosynthetic organisms. Another explanation for the unbalanced $\mathrm{N}$ budgets may be a bacterial release of methylamines and urea as suggested by Kroer et al. (1994). However, urea concentrations did not change significantly in the experiments. Phytoplankton is known to utilize urea as a source of $N$ (Antia et al. 1991), and we cannot exclude that a portion of the measured urea uptake was due to phytoplankton. However, since urea- $\mathrm{N}$ was a minor 
portion of the $\mathrm{N}$ uptake, an excess uptake of $\mathrm{N}$ would still occur.

Since bacterial carbon and nitrogen demand was higher at the eelgrass and diatom sediments, the bacteria retained 2 to 4 times more nitrogen in their biomass than at the bare sediment. Consequently, input of DOC from eelgrass and benthic algae may reduce the bacterial mineralization of DON and cause a temporary immobilization of nitrogen in pelagic bacterial biomass

The portion of the DOM efflux that accumulated in the water column after the incubations had a $\mathrm{C}: \mathrm{N}$ ratio of 5.9 to 6.1 (Figs. $1 \& 2$ ). Since there was no measurable net flux of DFAA, DCAA and urea in any of the experiments, the part of the DON flux that accumulated in the water must have consisted of other compounds than amino acids and urea. Assuming that stimulation of the bacterial DFAA and DCAA uptake (Tables $2 \& 3$ ) was caused by an amino acid input from the sediment, the released DFAA and DCAA constituted 5 to $6 \%$ of the total DON flux (Figs. $1 \& 2$ ). Thus, only a small fraction of the dissolved organic material released from the sediment in this experiment seemed readily available for the pelagic bacteria, although it had a high nitrogen content. However, the relatively small input of labile substrate had a significant influence on the pelagic bacterial production. Previous studies of the composition of interstitial nitrogen pools in seagrass beds (Boon 1986) support this observation. Boon (1986) found that DON constituted the majority ( 75 to $85 \%$ ) of the interstitial $N$, and that primary amines only comprised 5 to $10 \%$ of the total DON.

The significantly higher bacterial carbon demand and the direct positive effect of the eelgrass sediment and the diatom sediment (day expt) on the bacterial growth (Figs. 1 \& 2, Tables $2 \& 3$ ) suggest that these 2 sediment types did influence pelagic bacterial turnover of carbon and nitrogen. On the other hand, the bare sediment seemed only to have minor effects on the pelagic nutrient turnover. Therefore, large horizontal variations in pelagic $\mathrm{C}$ and $\mathrm{N}$ metabolism may occur in shallow environments with variable eelgrass cover and sediment structure.

\section{Diel variations}

Significant diel variations in the pelagic $C$ and $N$ turnover were found only for the bare sediment and the diatom sediment (Tables $2 \& 3$, Fig. 2).

The increased bacterial production in the bare sediment incubations at night coincided with a significantly higher DFAA uptake. In fact, the increase in DFAA uptake from day to night could account for 70 to $100 \%$ of the increase in bacterial C production, assum- ing a carbon content of $3.1 \mathrm{C}$ atoms per amino acid. This suggested that DFAA constituted the dominant carbon source for the bacteria at the bare sediment.

For the diatom sediment, bacterial production was highest during the day (Table 3) and, similar to the bare sediment, the higher bacterial production coincided with a higher DFAA uptake. In this case, however, DFAA uptake could only sustain about $20 \%$ of the increase in $C$ demand. This underlined the hypothesis that DOC input other than DFAA from the sediment in the day experiment was the primary cause for the increased $C$ demand (Table 3, Fig, 2). Thus, diel variations in bacterial production may be ascribed to changes in the input of labile DOC and amino acids from the sediment.

The higher net efflux of ammonium during the night incubations in the diatom sediment was probably due to an increased ammonium release from the sediment, as the ammonium uptake in the control incubations was similar during day and night (Fig. 3). This enhanced efflux of ammonium at night may be due to an increased mineralization in the sediment or to a reduced uptake of ammonium by benthic microalgae.

\section{Conclusion}

Our data show that exchange of organic matter in the sediment-water interface may have a strong influence on the pelagic bacterial production and on the composition of the substrates utilized by the bacterioplankton. Furthermore, the effects of the sediment on pelagic $C$ and $N$ turnover appeared to be influenced by the presence and activity of benthic microalgae and macrophytes. "We suggest that release of biodegradable DOM from these organisms stimulates the bacterioplankton production, resulting in a temporary immobilization of $\mathrm{N}$ in pelagic bacterial biomass. Finally, our data confirm that DON may be the dominant form of nitrogen released from sediments.

Acknowledgements. The study was supported by the Danish Strategic Environmental Research Programme and the Carlsberg Foundation. We thank Regitze Jensen for technical assistance.

\section{LITERATURE CITED}

Antia NJ, Harrison PJ, Oliveira L (1991) The role of dissolved organic nitrogen in the phytoplankton nutrition, cell biology and ecology. Phycologia 30:1-89

Boon PI (1986) Nitrogen pools in seagrass beds of Cymodocea serrulate and Zostera Capricorni of Moreton Bay, Australia. Aquat Bot 25:1-19

Christensen JP, Rowe GT, Clifford CH (1983) The possible 
importance of primary amino nitrogen in nitrogen regeneration by coastal marine sediments in Buzzards Bay, Massachusetts. Int Rev Ges Hydrobiol 68:501-512

Ducklow HW, Kirchman DL, Quinby HL, Carlson CA, Dam HG (1993) Stocks and dynamics of bacterioplankton carbon during the spring bloom in the eastern North Atlantic Ocean. Deep Sea Res 40:245-263

Fuhrman JA, Azam F (1980) Bacterioplankton secondary production estimates for coastal waters of British Columbia, Antarctica and California. Appl Environ Microbiol 39 1085-1095

Hobbie JE, Daley J, Jasper S (1977) Use of Nuclepore filters for counting bacteria by epifluorescence microscopy. Appl Environ Microbiol 33:1225-1228

Holmer M (1996) Composition and fate of dissolved organic carbon derived from phytoplankton detritus in coastal marine sediments. Mar Ecol Prog Ser 141:217-228

Hoppe HG, Kim SJ, Gocke K (1988) Microbial decomposition in aquatic environments: combined process of extracellular enzyme activity and substrate uptake. Appl Environ Microbiol 54:784-790

Hough RA, Wetzel RG (1975) The release of dissolved organic carbon from submersed aquatic macrophytes: diel, seasonal, and community relationships. Verh Int Verein Limnol 19:939-948

Jensen LM (1983) Phytoplankton release of extracellular organic carbon, molecular weight composition and bacterial assimilation. Mar Ecol Prog Ser 11:39-48

Jorgensen NOG, Blackburn TH, Henriksen K, Bay D (1981) The importance of Posidonia oceanica and Cymodocea nodosa as contributors of free amino acids in water and sediments of seagrass beds. PSZN I: Mar Ecol 2:97-112

Jørgensen NOG, Jensen RE (1997) Determination of dissolved combined amino acids using microwave-assisted hydrolysis and HPLC precolumn derivatization for labeling of primary and secondary amines. Mar Chem 57: $287-298$

Jørgensen NOG, Kroer N, Coffin RB, Yang XH, Lee C (1993) Dissolved free amino acids, combined amino acids and DNA as sources of carbon and nitrogen to marine bacteria Mar Ecol Prog Ser 98:135-148

Kairesalo T, Tuominen L, Hartikainen H, Rankinen K (1996) The role of bacteria in the nutrient exchange between sediment and water in a flow-through system. Microb Ecol 29:129-144

Keil RG, Kirchman DL (1993) Dissolved combined amino acids: chemical form and utilization by marine bacteria Limnol Oceanogr 38(6):1256-1270

Kirchman DL, Keil Y, Wheeler PA (1989) The effect of amino acids on ammonium utilization and regeneration by heterotrophic bacteria in the subarctic Pacific. Deep Sea Res 36:1963-1776

Kroer N (1.993) Bacterial growth efficiency on natural dissolved organic matter. Limnol Oceanogr 38:1282-1290

Kroer N (1994) Reldionships between biovolume and carbon

Editorial responsibility: Frede Thingstad,

Roskilde, Denmark and nitrogen content of bacterioplankton. FEMS Microbiol Ecol 13:217-224

Kroer N, Jørgensen NOG, Coffin RB (1994) Utilization of dissolved nitrogen by heterotrophic bacterioplankton: a cross-ecosystem comparison. Appl Environ Microbiol 60 : $4116-4123$

Lindroth P, Mopper K (1979) High performance liquid chromatographic determinations of subpicomolar amounts of amino acids by precolumn fluorescence derivatization with o-phthaldialdehyde. Anal Chem 51:1667-1674

Lomstein BAa and 8 others (1995) Omsatning af organisk kvælstof $i$ marine sedimenter. The Danish Environmental Protection Agency, Copenhagen, 58:1-94

Lomstein BAa, Blackburn TH (1992) Sediment nitrogen cycling in Árhus Bay, Denmark. The Danish Environmental Protection Agency, Copenhagen, 16:1-74

Mann CJ, Wetzel RG (1996) Loading and utilization of dissolved organic carbon from emergent macrophytes. Aquat Bot 53:61-72

Middelboe M, Borch NH, Kirchman DL (1995) Bacterial utilization of dissolved free amino acids, dissolved combined amino acids and ammonium in the Delaware Bay estuary: effects of carbon and nitrogen limitation. Mar Ecol Prog Ser 128:109-120

Middelboe M, Nielsen B, Søndergaard M (1992) Bacterial utilization of dissolved organic carbon (DOC) in coastal waters-determination of growth yield. Arch Hydrobiol Ergebn Limnol 37:51-61

Pakulski JD (1986) The release of reducing sugars and dissolved organic carbon from Spartina alterniflora Loisel in a Georgia salt marsh. Estuar Coast Shelf Sci 22:385-394

Pedersen MF, Borum J (1992) Nitrogen dynamics of eelgrass Zostera marina during a late summer period of high growth and low nutrient availability. Mar Ecol Prog Ser 80:65-73

Price NM, Harrison PJ (1987) Comparison of methods for the analysis of dissolved urea in seawater. Mar Biol 94: $307-317$

Riemann B, Bjørnsen PK, Newell S, Fallon R (1987) Calculation of cell production of coastal marine bacteria based on measured incorporation of ${ }^{3} \mathrm{H}$-thymidine. Limnol Oceanogr $32: 471-476$

Sloth NP, Blackburn TH, Hansen LS, Risgaard-Petersen NM, Lomstein BA (1995) Nitrogen cycling in sediments with different organic loading. Mar Ecol Prog Ser 116:163-170

Søndergaard M, Middelboe M (1993) Measurements of particulate organic carbon: a note on the use of glass fiber (GF/F) and Anodisc ${ }^{\circ}$ filters. Arch Hydrobiol 127:73-85

Turner RE (1993) Carbon, nitrogen, and phosphorus leaching rates from Spartina alterniflora salt marches. Mar Ecol Prog Ser 92:135-140

Viles $\mathrm{CH}_{1}$ Sieracki ME (1992) Measurement of marine picoplankton cell size by using a cooled, charge-coupled device camera with image-analyzed fluorescence microscopy Appl Fnviron Microbiol 58(2):584-592

Submitted: June 20, 1997; Accepted: August 14, 1997

Proofs received from author(s): September 9,1997 